\title{
Monitoring and health risk assessment of selected trace metals in wheat rice and soil samples
}

\author{
Almas HAMID ${ }^{1 \star}$ (D), Amen WASIM ${ }^{1}$, Amna AZFAR ${ }^{1}$, Ramsha AMJAD¹, Rabia NAZIR ${ }^{2}$
}

\begin{abstract}
Wheat and rice constitute important cereal crops and any contamination may pose potential adverse impacts on human health. The study was conducted to determine eight trace metals, i.e. cadmium $(\mathrm{Cd})$, copper $(\mathrm{Cu})$, cobalt $(\mathrm{Co})$, chromium $(\mathrm{Cr})$, zinc $(\mathrm{Zn})$, lead $(\mathrm{Pb})$, nickel $(\mathrm{Ni})$, manganese $(\mathrm{Mn})$, in wheat, rice and soil samples collected from different cities of Punjab. Results showed general trend of trace element accumulation in samples as $\mathrm{Cd}>\mathrm{Cu}>\mathrm{Zn}>\mathrm{Co}>\mathrm{Mn}$. All wheat and nine rice samples exceeded permissible limit of $\mathrm{Cd}$. Copper in eight wheat and rice samples and $\mathrm{Zn}$ levels in three wheat and one rice samples were in excess. While only one soil sample of Multan exceeded the WHO 2007 and EU 2000 maximum allowable limit for Cu. Manganese and $\mathrm{Co}$ concentration were within allowable limit, while $\mathrm{Ni}, \mathrm{Cr}$ and $\mathrm{Pb}$ were not detected in any sample. Health Risk Index was higher than 1 for $\mathrm{Cu}, \mathrm{Cd}$, Co and $\mathrm{Mn}$ thereby showing potential health risks to consumers.
\end{abstract}

Keywords: trace metals; wheat; rice; health risk index.

Practical Application: Wheat and rice are widely consumed source of food worldwide. Therefore, this food group is important in agriculture and any contamination of this commodity with unwanted chemicals is a matter of grave concern. The increasing apprehension regarding food safety stimulated the research regarding pollution of trace metals in wheat and rice is an issue and must be monitored by the relevant authorities.

\section{Introduction}

Agriculture sector of Pakistan plays a dominant role in the economy with significant contribution (18.9 percent) to Gross Domestic Product (GDP). The sector provides employment to about 42.3 percent of total labor force and is most important in terms of foreign exchange earnings (Government of Pakistan, 2017).

Wheat and rice are amongst the most important cereal crop grown and consumed around the world. Among the wheat producing countries of the world, Pakistan is ranked $8^{\text {th }}$ in terms of area under wheat cultivation, production and yield per hectare (Riazuddin et al., 2011). With an area of 8,972 thousand hectares and a total production of 25.492 million tonnes during 2017-18, it contributed to $1.7 \%$ of GDP and $9.1 \%$ to the total value added in agriculture. Similarly, rice added to about $1.3-1.6 \%$ of GDP (Pakistan Economic survey, 2017).

Cereal crops are major source of nutrients and the most commonly cultivated food in Pakistan. Therefore, this food group is important in agriculture and contamination of this commodity with unwanted chemicals is viewed with concern. The increasing concern regarding food safety stimulated research regarding contamination of food stuffs with different toxins such as pesticides and trace metals (Riazuddin et al., 2011).

Contamination of different food stuffs like meat, milk, vegetables, sea weeds etc. is highly prevalent and often widely reported around the world (Khan et al., 2018; Wang et al., 2019;
Liang et al., 2018; Roleda et al., 2019). Trace metals (TMs) constitute one of the major contaminants of food commodities, the sources of which can be traced to the application of contaminated irrigation water, use of fertilizers and pesticides and industrial activities etc.

Studies have shown high concentration of TMs in different areas in Pakistan, including wheat samples analyzed from Abbottabad, Khyber Pakhtunkhwa (Hassan et al., 2013). A similar study carried out to evaluate the role of sewage sludge in increased concentrations of TMs showed that wheat grown on soil amended with sludge had high concentrations of lead $(\mathrm{Pb})$ and $\mathrm{Cd}$ (Jamali et al., 2009). These metals not only persist in the environment but are also toxic to humans and animals since they cause cancers, mutations, teratogenicity, disruption of hormones, skin, eyes irritation, headache, nausea, dizziness, poisoning, coma, endocrine disruption, respiratory illness, convulsions, liver damage, tremors, decreased fertility, effects on central nervous system, kidneys, abdominal pain and loss of muscle coordination (Jaishankar et al., 2014; Roberts \& Relgart, 2013). A study conducted in Sialkot and Gujranwala districts to determine HRI of TMs in wheat and some vegetables depicted that maximum HRI was observed in wheat samples of both areas with values up to 8.9 and 9.9 , respectively. Hence, the population of study areas may experience serious health risks especially because of consumption of wheat (Khan et al., 2014). 
The present study focused on determination of TMs; $\mathrm{Cd}, \mathrm{Cr}, \mathrm{Zn}, \mathrm{Mn}, \mathrm{Cu}, \mathrm{Co}, \mathrm{Pb}$ and $\mathrm{Ni}$ in wheat, rice and soil samples and subsequent risk to human health.

\section{Materials and methods}

Wheat $(W ; n=15)$, rice $(R ; n=11)$ and soil $(S ; n=13)$ samples were collected from different areas including Kala Shah Kaku (KSK W1, KSK R1), Multan (MW1, MW2, MW3, MS1 MS2, MS3), Lahore (LW1, LW2, LW3, LW4,LR1, LR2, LR3, LR4, LS1, LS2, LS3, LS4), Minchinabad (MAW1, MAW2, MA R1, MAR2, MAS1, MAS2) Sargodha (SR W1, SRW2, SR R1, SRS1, SRS2), Eminabad (AMN W1, AMN R1) and Sheikhupura (SKPW1, SKPW2, SKP R1, SKP R2,SKPS1, SKPS2) (Figure 1). These areas were selected on the basis of their rich agricultural productivity. The TMs analyzed included $\mathrm{Ni}, \mathrm{Cd}, \mathrm{Mn}, \mathrm{Zn}, \mathrm{Cu}$, $\mathrm{Co}$ and $\mathrm{Pb}$. Stock solutions of $100 \mathrm{mg} \mathrm{L}^{-1}$ were prepared by diluting the respective metals' CRM with distilled water. From this, working solutions were prepared using calibrated glass ware.

\subsection{Preparation of samples}

100 - $200 \mathrm{~g}$ of sample was collected by coning and quartering and whole sample was mixed well followed by grinding in clean \& oven dried pestle and mortar and sieved through a 20 mesh sieve. The ground sample was stored in air-tight jar before further use.

Estimation of trace metals in wheat, rice and soil samples

\section{Extraction of TMs}

Standard USEPA method 3015A, with some modifications, was followed for sample preparation for metal analysis (United States Environmental Protection Agency, 2007a). Two solutions were made using hydrogen peroxide and nitric acid. The solution
A contained $30 \mathrm{~mL}$ hydrogen peroxide and $70 \mathrm{~mL}$ distilled water. Solution B contained $50 \mathrm{~mL}$ nitric acid and $50 \mathrm{~mL}$ distilled water. Weighed $2 \mathrm{~g}$ each of respective sample i.e. wheat/rice/soil and transferred into round bottom flask in which $5 \mathrm{~mL}$ of solution $\mathrm{A}$, $5 \mathrm{~mL}$ of solution $\mathrm{B}$ and $10 \mathrm{~mL}$ distilled water were added. This round bottom flask was placed in a beaker containing silica gel. To keep the flask intact in its position thermopol sheet was cut and placed at the neck of the flask and as a cork on top of it.

Once the sample solution was made and initial reaction subsides, the beaker containing silica gel and round bottom flask was placed into microwave for 40 seconds for digestion of the sample. However, after every 10 second the beaker was taken out and allowed to cool. After digestion, the round bottom flask contents was filtered using Whatman filter paper 41 and the filtrate was diluted up to the mark in $100 \mathrm{~mL}$ volumetric/ flask with distilled water.

Same procedure was followed for rice and soil samples.

\section{Metal analysis using AAS}

Metals were determined using AAS (model 210VGP) as per standard USEPA method number 7000B (United States Environmental Protection Agency, 2007b). Graph between the concentration and the absorbance of standard solutions was drawn. The standards for each metal ion were prepared as 0.01ppm, 0.05ppm, 0.1ppm, 0.5ppm, 1ppm, 2ppm, 5ppm, 10ppm, 20ppm, 50ppm and $100 \mathrm{ppm}$. Concentration of the metals was determined using calibration curves. The correlation coefficients R2 (calibration curve), were in the range of 0.9817 and 0.9970 . The instrumental limit of detection (LOD) and limit of quantification (LOQ) were determined by using certified reference materials of the respective metals supplied by VWR, which are given in Table 1.

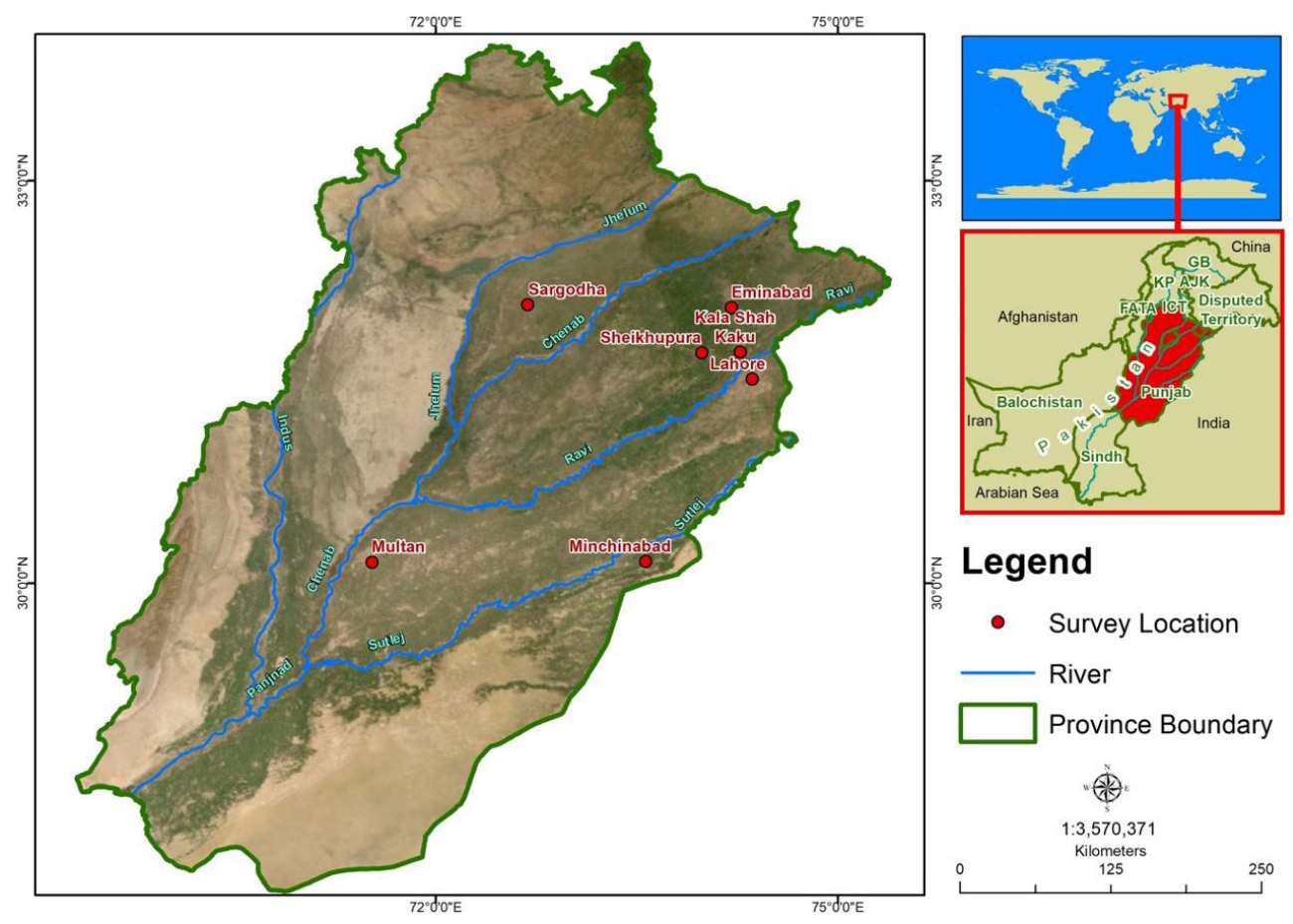

Figure1. Location map of study areas. 


\subsection{Determination of Health Risk Index (HRI)}

Health risk index was calculated using the following formula (Equation 1)

$$
H R I=D I M / R f D
$$

Here RfD is reference oral dose and according to EPA, its values are $0.14,0.3,0.04,0.001,0.043 \mathrm{mg} \mathrm{kg}^{-1} \mathrm{day}^{-1}$ for $\mathrm{Mn}, \mathrm{Zn}$, $\mathrm{Cu}, \mathrm{Cd}$, and Co, respectively (United States Environmental Protection Agency, 2010). DIM is Daily intake of Metals and it was calculated using formula (Equation 2)

$$
D I M=\frac{\text { Conc. of Metal } \times \text { Daily food intake }}{\text { Average body weight }}
$$

Taking average body weight in Pakistan $72 \mathrm{~kg}$, average rice consumption per capita $0.15 \mathrm{~kg}$ day $^{-1}$ (JCR-VIS Credit Rating Company Limited, 2017) and average wheat consumption per capita $0.34 \mathrm{~kg} \mathrm{day}^{-1}$ (Global International Information Network, 2017).

An HRI index value of more than 1 is considered unsafe for human health (United States Environmental Protection Agency, 2010).

\subsection{Target Hazard Quotient (THQ)}

THQ of trace metals was calculated using following Equation 3 (Zhuang et al., 2009);

$$
\boldsymbol{T H Q}=\frac{\boldsymbol{E F r} \times \boldsymbol{E D} \times \boldsymbol{F I} \times \boldsymbol{M C}}{\boldsymbol{R} \boldsymbol{f D} \times \boldsymbol{B W} \times \boldsymbol{A T}} \times 10^{-3}
$$

Here, EFr is exposure frequency (365 days per year), ED is exposure duration which is basically the life expectancy (66.5 years for Pakistan as reported by WHO), FI is food ingestion rate $\left(\mathrm{kg}\right.$ person ${ }^{-1}$ day $\left.^{-1}\right), \mathrm{MC}$ is metal concentration in $\mathrm{mg} \mathrm{kg}^{-1}, \mathrm{RfD}$ is reference dose, BW is body weight (72 kg), and AT is average exposure time (365 days year ${ }^{-1} \times$ number of exposure years, assuming 66.5 years.

\section{Results and discussion}

Eight metals Ni, Mn, Zn, Co, Cd, Co, Cr, Pb were investigated in wheat, rice and soil samples. Metal concentration varies in wheat and rice depending upon the soil, water used for irrigation and the climate of the cultivated area whereas for soil the metal concentration is mostly higher when compared to the crops grown on that soil.

Out of all metals analyzed, $\mathrm{Pb}, \mathrm{Ni}$ and $\mathrm{Cr}$ were not detected in any sample whereas the concentrations of other five metals are mentioned in Table 2-4.

Table 1. Instrumental Limit of detection (LOD) and limit of quantification (LOQ) of the trace metals.

\begin{tabular}{|c|c|c|c|c|c|}
\hline \multirow{2}{*}{ Sample code } & \multicolumn{5}{|c|}{ Trace metals concentration $\left(\mathrm{mg} \mathrm{kg}^{-1}\right)$} \\
\hline & $\mathrm{Mn}$ & $\mathrm{Zn}$ & $\mathrm{Cu}$ & $\mathrm{Cd}$ & Co \\
\hline AMNW1 & 34 & 43.75 & 88 & 0.25 & 37.5 \\
\hline KSKW1 & 36.25 & 57.75 & 44 & 0.25 & 58.25 \\
\hline LW1 & 48.25 & 58.5 & 16.5 & 0.25 & 25 \\
\hline LW2 & 50 & 34.75 & 51.07 & 0.25 & 25 \\
\hline LW3 & 0.75 & 26 & 2.5 & 1.25 & ND \\
\hline LW4 & 31.75 & 44 & 2.25 & 0.25 & 25 \\
\hline MAW1 & 38.75 & 45 & 31.89 & 0.25 & 12.5 \\
\hline MAW2 & 31.75 & 26.5 & 1.75 & 0.25 & 50 \\
\hline MW1 & 50 & 42.75 & 2.5 & 14 & 54.25 \\
\hline MW2 & 38.5 & 50 & 2.0 & 2.5 & 2.5 \\
\hline MW3 & 50 & 28 & 2.25 & 0.25 & 12.5 \\
\hline SKPW1 & 20.75 & 37.75 & 44.75 & 14 & 50 \\
\hline SKPW2 & ND & 45 & 20.8 & 1.25 & 54.25 \\
\hline SRW1 & 50 & 31.75 & 40.5 & 0.25 & 12.5 \\
\hline SRW2 & ND & 16.25 & ND & 0.25 & ND \\
\hline Max. concentration & 50 & 58.5 & 88 & 14 & 58.25 \\
\hline Min. concentration & 0.75 & 16.25 & 1.75 & 0.25 & 2.5 \\
\hline Standards (World Health Organization, 2004) & 500 & 50 & 3.0 & $0.20 / 0.1$ & - \\
\hline
\end{tabular}

\begin{tabular}{cccccccc}
\hline Metals & $\mathrm{Cd}$ & $\mathrm{Co}$ & $\mathrm{Cr}$ & $\mathrm{Ni}$ & $\mathrm{Zn}$ & $\mathrm{Mn}$ & $\mathrm{Cu}$ \\
\hline LOD mg/l & 0.01 & 0.05 & 0.04 & 0.05 & 0.005 & 0.03 & 0.005 \\
LOQ mg/l & 0.03 & 0.15 & 0.12 & 0.151 & 0.015 & 0.09 & 0.015 \\
\hline
\end{tabular}

Table 2. Concentrations of trace metals in wheat samples. 
Table 3. Concentrations of trace metals in rice samples.

\begin{tabular}{|c|c|c|c|c|c|}
\hline \multirow{2}{*}{ Sample Code } & \multicolumn{5}{|c|}{ Concentration of Trace Metals in mg kg-1 } \\
\hline & $\mathrm{Mn}$ & $\mathrm{Zn}$ & $\mathrm{Cu}$ & $\mathrm{Cd}$ & Co \\
\hline AMN R1 & ND & 29 & ND & 0.25 & 2.5 \\
\hline KSKR1 & 7.5 & 25 & ND & 0.25 & 12.5 \\
\hline LR1 & 25 & 46 & 65.25 & ND & 12.5 \\
\hline LR2 & 110 & 19.25 & 352.75 & 17.5 & 2.5 \\
\hline LR3 & ND & 12.5 & ND & 1.25 & ND \\
\hline LR4 & 25 & 90 & 51.07 & 12.5 & ND \\
\hline MAR1 & 20 & 26.25 & 432.25 & 17.5 & 0.25 \\
\hline MAR2 & 18.75 & 26.25 & 277.5 & 17.5 & 12.5 \\
\hline SKPR1 & 18.75 & 27.5 & 68.5 & ND & 37.5 \\
\hline SKPR2 & 1.25 & 33.75 & 57.6 & 5.0 & ND \\
\hline SRR1 & 20 & 40 & 54.25 & 17.5 & 2.5 \\
\hline Max. concentration & 110 & 90 & 432.25 & 17.5 & 37.5 \\
\hline Min. concentration & 1.25 & 12.5 & 51.07 & 0.25 & 0.25 \\
\hline $\begin{array}{c}\text { Standards } \\
\text { (European Union, 2002; World Health } \\
\text { Organization, 2004) }\end{array}$ & 500 & 50 & 3.0 & $0.20 / 0.1$ & - \\
\hline
\end{tabular}

Table 4. Concentration of trace metals in soil samples.

\begin{tabular}{|c|c|c|c|c|c|}
\hline \multirow{2}{*}{ Sample code } & \multicolumn{5}{|c|}{ Trace metals concentration (mg kg-1) } \\
\hline & $\mathrm{Mn}$ & $\mathrm{Zn}$ & $\mathrm{Cu}$ & $\mathrm{Cd}$ & Co \\
\hline LS1 & 120 & 44 & 20.8 & 16 & 2.5 \\
\hline LS2 & 392.5 & 34 & 31 & 13 & 12.5 \\
\hline LS3 & 303.75 & 47 & 36.25 & 50 & 0.25 \\
\hline LS4 & 83.25 & 40.75 & 27.5 & 66 & 12.5 \\
\hline MAS1 & 58.75 & 41.75 & 41.5 & 17 & 0.25 \\
\hline MS2 & 132.5 & 28.5 & 20.8 & 25 & 02.5 \\
\hline MS3 & 254.25 & 28 & 27.5 & 33 & 2.5 \\
\hline SKPS1 & 144 & 37.5 & 27.5 & ND & 2.5 \\
\hline SKPS2 & 250 & 50 & 29.25 & 63 & ND \\
\hline SRS1 & 259.5 & 35.25 & 93.5 & 35 & 0.25 \\
\hline $\begin{array}{c}\text { Standards } \\
\text { (Awashthi, 2000; } \\
\text { European Union, 2002) }\end{array}$ & - & $300-600$ & $100 / 140$ & $3-6$ & 60 \\
\hline
\end{tabular}

Three (20\%) wheat samples; M W2 (50 $\left.\mathrm{mg} \mathrm{kg}^{-1}\right)$, L W1 (58.5 $\mathrm{mg} \mathrm{kg}^{-1}$ ) and KSK W1 (57.75 $\left.\mathrm{mg} \mathrm{kg}^{-1}\right)$ exceeded the maximum allowable limit (MAL) of $50 \mathrm{mg} \mathrm{kg}^{-1}$ (World Health Organization, 2004) for $\mathrm{Zn}$ with highest being $17 \%$ more than the standard. In similar studies conducted earlier, $\mathrm{Zn}$ was reported to be as low as $35.5 \mathrm{mg} \mathrm{kg}^{-1}$ (Hassan et al., 2013) and between $108-133 \mathrm{mg} \mathrm{kg}^{-1}$ in wheat grains in Pakistan (Jamali et al., 2009).

One rice sample L R4 ( $\left.90 \mathrm{mg} \mathrm{kg}^{-1}\right)$ exceeded the permissible limit being almost double the standard value. Zinc contaminated food crops can adversely affect human health. High zinc concentration in food crops can damage pancreas and hinder the protein functioning in a human body (Jaishankar et al., 2014). The MAL of $\mathrm{Zn}$ in soil, according to Indian standards 2000, is $300-600 \mathrm{mg} \mathrm{kg}^{-1}$. None of the soil sample exceeded the MAL.
The permissible level of $\mathrm{Cu}$ in wheat and rice is $3 \mathrm{mg} \mathrm{kg}^{-1}$ (World Health Organization, 2004). The results showed that $53 \%$ wheat samples (LW1, LW2, KSK W1, SKP W1, SKP W2, MA W1, SR W1 and AMN W1) exceeded the MAL (average value of 25.1 \pm 26.1 ) while rest of the analyzed samples showed levels between the range of 1.75-2.5 $\mathrm{mg} \mathrm{kg}^{-1}$. Other studies from Pakistan reported Cu levels in the range of 3.1-5.1 $\mathrm{mg} \mathrm{kg}^{-1}$ (Hassan et al., 2013) and $11.8 \mathrm{mg} \mathrm{kg}^{-1}$ in wheat samples (Jamali et al., 2009). Elsewhere, Bermudez et al. (2011) reported $\mathrm{Zn}$ (range 7.8-56.4 $\mathrm{mg} \mathrm{kg}^{-1}$ ) and $\mathrm{Cu}$ levels (range $1.25-6.93 \mathrm{mg} \mathrm{kg}^{-1}$ ) in wheat grains to be higher than the standard limits set by FAO/WHO.

Copper concentrations were very high in eight $(72 \%)$ rice samples. In another study conducted in China, 38 rice cultivars were examined for $\mathrm{Cu}, \mathrm{Cd}$ and $\mathrm{Hg}$ levels. However, all rice samples 
had $\mathrm{Cu}$ concentration lower or close to the maximum safe intake level with range of 1.81-6.54 $\mathrm{mg} \mathrm{kg}^{-1}$ (He et al., 2013). Copper is important for plant growth and is available in soil and sediments. It is also an essential element for human health which is naturally present in wide range of food varieties e.g. beef liver, beans, nuts etc. but exceeding levels may result in anemia, damage liver and kidney and cause intestinal irritation. Even though acute and chronic poisoning of $\mathrm{Cu}$ is not common in humans a prolonged exposure to excessive $\mathrm{Cu}$ levels may result in adverse reactions on liver (Jaishankar et al., 2014; Oosthuizen, 2012).

In the present study, though all soil samples, except M S1 (262.75 $\mathrm{mg} \mathrm{kg}^{-1}$, with almost twice the standard value), had Cu levels less than the permissible limit (European Union, 2002) yet these were higher than reported by other similar study in Pakistan which was in the range of 3.1-5.1 $\mathrm{mg} \mathrm{kg}^{-1}$ (Hassan et al., 2013). Cu concentration varies in various soil samples depending upon the soil type and pollution source. Fungicide sprays that are used on farm are also laden with $\mathrm{Cu}$ that may result in contamination. The soil to plant transfer of $\mathrm{Cu}$ determines the level of human exposure to copper.

All wheat samples exceeded the MAL $\left(0.2 \mathrm{mg} \mathrm{kg}^{-1}\right)$ of $\mathrm{Cd}$ with maximum concentration $\left(14 \mathrm{mg} \mathrm{kg}^{-1}\right)$ of Cd in M W1 \& SKPW1which is much higher than reported earlier who also identified major reasons for higher levels of Cd to be wastewater irrigation or soil amendment by sewage sludge which changes the $\mathrm{pH}$ of soil. Nevertheless, most samples had Cd content similar as reported (Hassan et al., 2013). Other studies in Pakistan also reported higher $\mathrm{Cd}$ concentration in wastewater used for agriculture. One such study showed Cd levels in the range 0.18-0.37 $\mathrm{mg} \mathrm{kg}^{-1}$ in Lahore (Mahmood \& Malik, 2014). Whereas, in Iran, Co and Cd levels in wheat were found to be below detection limit $\left(0.015 \mu \mathrm{g} \mathrm{g}^{-1} \& 0.0047 \mu \mathrm{g} \mathrm{g}^{-1}\right.$ respectively) in all samples, whereas mean concentration of $\mathrm{Cu}$ was $0.501 \mu \mathrm{g} \mathrm{g}^{-1}$ (Esmaili et al., 2017).

Likewise, $81 \%$ of rice samples exceeded MAL $\left(0.20 \mathrm{mg} \mathrm{kg}^{-1}\right)$ for Cd level with a maximum concentration of $17.5 \mathrm{mg} \mathrm{kg}^{-1}$ and minimum of $0.25 \mathrm{mg} \mathrm{kg}^{-1}$. Similar study was conducted in Iran to determine the level of arsenic, $\mathrm{Cd}$ and lead $(\mathrm{Pb})$ in rice samples, imported from Pakistan and India. Concentration of $\mathrm{Pb}$ and Cd were considerably higher than the safe limit by FAO/WHO (Roya \& Ali, 2017). In another study carried out in Saudi Arabia, Cd concentration measured in 37 brands of imported rice showed higher levels than the standard limits. However, it has been demonstrated that soaking or rinsing rice grains with water helped decrease Cd to acceptable levels. Huo et al. (2016) found that $\mathrm{Cd}$ in rice could be reduced by $>95 \%$ by washing with citric acid, due to breaking of bond between $\mathrm{Cd}$ and rice protein (Al-Saleh \& Abduljabbar, 2017). Amir et al. (2019) has also reported the potential of citric acid to effectively reduce metal content from vegetables.

As expected, all the analyzed soil samples also showed Cd values higher than the MAL compared to allowable concentration of 3-6 $\mathrm{mg} \mathrm{kg}^{-1}$ (Awashthi, 2000).

Cadmium is one of the most toxic heavy metals because it is highly mobile in soil. It can damage human health at each level from cell formation to body functioning and acute or chronic intoxication. Application of fertilizer and sewage sludge on farm leads to soil contamination and increased uptake by plants especially at low $\mathrm{pH}$. Moreover, farmers in developing countries like Pakistan and India use effluent for irrigation which becomes a source of many toxic metals (Chandra et al., 2009; Abbas et al., 2007). Studies have also shown that $\mathrm{Cd}$ can remain in soil for several decades and is slowly taken up by plants, accumulated and then concentrated along the food chain, reaching human body. Prolonged exposure of Cd to human body leads to kidney failure, liver failure and damage to central and peripheral nervous system. (Al-Saleh \& Abduljabbar, 2017; Jaishankar et al., 2014; Oosthuizen, 2012; Malik et al., 2010).

The mean concentration of Co in wheat and rice samples was $32.3 \pm 14.3$ and $10.34 \pm 12.2 \mathrm{mg} \mathrm{kg}^{-1}$ respectively. Whereas none of the soil samples exceeded the limit $\left(60 \mathrm{mg} \mathrm{kg}^{-1}\right)$ given by Indian regulations 2000 (Awashthi, 2000). When a high Co level is readily available, in polluted soil in particular, it can seriously affect plant growth and metabolic functions. The Co concentration of 25 and $50 \mathrm{ppm}$ in soil is toxic to rice plants (Pendias \& Pendias, 2001).

Manganese is important for growth, skeletal formation and reproductive functioning in humans and animals and its deficiency can lead to diabetes, bone disorder, stunted growth in infants and children and nervous system instability, whereas, in adults it can lead to arthritis (Rehman et al., 2017). It is also considered essential for the metabolic processes in plants. The Mn content in wheat samples was within limits and consistent with mean concentration in wheat grains and wheat flour reported in similar studies in Pakistan as $4.9 \mathrm{mg} \mathrm{kg}^{-1}$ (Hassan et al., 2013) and $38.1 \mathrm{mg} \mathrm{kg}^{-1}$ (Hussain et al., 2011). In soil samples, Mn concentration were much higher than reported in India where Mn levels in soil and grain (wheat) samples were reported as 154-194 $\mathrm{mg} \mathrm{kg}^{-1}$ and 11.19-40.57 $\mathrm{mg} \mathrm{kg}^{-1}$ respectively (Vanita et al., 2014).

Highest concentrations of TMs were detected mostly in the samples of Eminabad, Sheikhupura and Lahore.

\subsection{Health risk index}

Health risk index calculation showed potential for health risk due to presence of $\mathrm{Cu}, \mathrm{Cd}$ and $\mathrm{Co}$ in analyzed samples (Table 5).

Calculation of HRI of $\mathrm{Cu}$ indicates that $57 \%$ wheat samples while all rice samples had HRI value greater than 1 indicating potential high risk to human health. The HRI of Cd for all wheat samples was higher than 1 (average value 11.7) whereas, 78\% of rice samples had HRI greater than 1 . A total of $92 \%$ of the wheat samples while only 1 rice sample i.e. SKP R1 (1.81) had HRI value higher than 1 for Co. Whereas, for Mn $85 \%$ of wheat samples had HRI $>1$ with an average of 1.24 but only one rice sample had HRI greater than 1.

Similar study conducted in Swat shows HRI for Cd to be much higher as compared to $\mathrm{Cr}, \mathrm{Cu}, \mathrm{Mn}, \mathrm{Ni}$ and $\mathrm{Zn}$. Cadmium concentration was higher in all of the samples and it was observed that cereal grains were highly contaminated relative to fruits and vegetables. However, the risk assessment revealed that there were no health risks in the area for all TMS except Cd, which showed HRI > 1 (Khan et al., 
Table 5. HRI and THQ of trace metals in wheat and rice samples.

\begin{tabular}{|c|c|c|c|c|c|c|c|c|c|c|}
\hline \multirow{2}{*}{ Values } & \multicolumn{5}{|c|}{ HRI } & \multicolumn{5}{|c|}{ THQ } \\
\hline & Co & $\mathrm{Cd}$ & $\mathrm{Cu}$ & $\mathrm{Zn}$ & $\mathrm{Mn}$ & Co & $\mathrm{Cd}$ & $\mathrm{Cu}$ & $\mathrm{Zn}$ & $\mathrm{Mn}$ \\
\hline & \multicolumn{10}{|c|}{ Wheat } \\
\hline Minimum value & 0.25 & 1.18 & 0.20 & 0.25 & 0.025 & 0 & 0 & 0 & 0 & 0 \\
\hline Maximum value & 6.39 & 66.1 & 10.3 & 0.92 & 1.68 & 0 & 0.06 & 0 & 0 & 0.02 \\
\hline \multirow[t]{2}{*}{ Mean } & 3.53 & 11.7 & 2.94 & 0.61 & 1.24 & 0 & 0.01 & 0 & 0 & 0.001 \\
\hline & \multicolumn{10}{|c|}{ Rice } \\
\hline Minimum value & 0.01 & 0.52 & 2.65 & 0.08 & 0.018 & 0 & 0 & 0 & 0 & 0 \\
\hline Maximum value & 1.81 & 36.4 & 22.5 & 0.62 & 1.63 & 0 & 0.03 & 0.02 & 0 & 0.02 \\
\hline Mean & 0.49 & 20.62 & 8.82 & 0.23 & 0.40 & 0 & 0.016 & 0.005 & 0 & 0.0002 \\
\hline
\end{tabular}

2013). In a comparable study conducted in Sialkot and Gujranwala the values of HRI of TMs through consumption of wheat were found in the order of: $\mathrm{Pb}>\mathrm{Cd}>\mathrm{Ni}>\mathrm{Mn}>\mathrm{Fe}>\mathrm{Zn}>\mathrm{Cu}>\mathrm{Cr}$ in Sialkot and $\mathrm{Pb}>\mathrm{Cd}>\mathrm{Mn}>\mathrm{Ni}>\mathrm{Fe}>\mathrm{Zn}>\mathrm{Cu}>\mathrm{Cr}$ in Gujranwala. It was concluded that the population of these areas may experience a health risk because of the high consumption rate of wheat (Khan et al., 2014).

\section{Conclusion}

Trace metal accumulation is a rising concern in this era. These pollutants not only accumulate in the environment but also cause health hazards to humans. Among the studied metals, results show a substantial concentration of TMs in the samples. The general trend observed is in decreasing order $\mathrm{Cd}>\mathrm{Cu}>\mathrm{Zn}>\mathrm{Co}>\mathrm{Mn}$. It is suggested that a comprehensive study must be conducted to monitor and evaluate irrigation water quality, crops contamination and the prevalent health risk in these and other food growing/ agriculture areas.

The HRI was found higher $(>1)$ for $\mathrm{Cd}, \mathrm{Cu}, \mathrm{Co}$, and $\mathrm{Mn}$ indicating potential health risk to consumers.

\section{References}

Abbas, S. T., Sarfraz, M., Mehdi, S. M., Hassan, G., \& Obaidurrehman, (2007). Trace elements accumulation in soil and rice plants irrigated with the contaminated water. Soil \& Tillage Research, 94(2), 503-509. http://dx.doi.org/10.1016/j.still.2006.10.004.

Al-Saleh, I., \& Abduljabbar, M. (2017). Heavy metals (lead, cadmium, methylmercury, arsenic) in commonly imported rice grains (Oryza sativa) sold in Saudi Arabia and their potential health risk. International Journal of Hygiene and Environmental Health, 220(7), 1168-1178. http://dx.doi.org/10.1016/j.ijheh.2017.07.007. PMid:28780210.

Amir, R. M., Randhawa, M. A., Sajid, M. W., Nadeem, M., Ahmad, A., \& Wattoo, F. M. (2019). Evaluation of various soaking agents as a novel tool for heavy metal residues mitigation from spinach. Food Science and Technology (Campinas), 39(1), 176-180. http://dx.doi. org/10.1590/fst.00118.

Awashthi, S. K. (2000). Prevention of Food Adulteration Act No. 37 of 1954. Central and State, Rules as Amended for 1999. New Delhi, India: Ashoka Law House.

Bermudez, G. M. A., Jasan, R., Plá, R., \& Pignata, L. M. (2011). Heavy metal and trace element concentrations in wheat grains: Assessment of potential non-carcinogenic health hazard through their consumption. Journal of Hazardous Materials, 193, 264-271. http://dx.doi.org/10.1016/j.jhazmat.2011.07.058. PMid:21835546.
Chandra, R., Bharagava, R. N., Yadav, S., \& Mohan, D. (2009). Accumulation and distribution of toxic metals in wheat (Triticum aestivum L.) and Indian mustard (Brassica campestris L.) irrigated with distillery and tannery effluents. Journal of Hazardous Materials, 162(2-3), 1514-1521. http://dx.doi.org/10.1016/j.jhazmat.2008.06.040. PMid:18650002.

Esmaili, A., Noroozi Karbasdehi, V., Saeedi, R., Javad Mohammadi, M., Sobhani, T., \& Dobaradaran, S. (2017). Data on heavy metal levels $(\mathrm{Cd}, \mathrm{Co}$, and $\mathrm{Cu})$ in wheat grains cultured in Dashtestan County, Iran. Data in Brief, 14, 543-547. http://dx.doi.org/10.1016/j. dib.2017.08.012. PMid:28861451.

European Union. (2002). Heavy Metals in Wastes. Brussels, Belgium: European Commission on Environment.

Global International Information Network. (2017). Pakistan: Grain and Feed Annual. Retrieved from https://gain.fas.usda.gov/ Recent\%20GAIN\%20Publications/Grain\%20and\%20Feed\%20 Annual_Islamabad_Pakistan_4-3-2017.pdf

Government of Pakistan. Ministry of Finance. (2017). Pakistan Economic Survey (2017-18): Agriculture. Pakistan. Retrieved from http://www. finance.gov.pk/survey/chapters_17/02-Agriculture.pdf

Hassan, N. U., Mahmood, Q., Waseem, A., Irshad, M., \& Pervez, A. (2013). Assessment of Heavy Metals in Wheat Plants Irrigated with Contaminated Wastewater. Polish Journal of Environmental Studies, 22(1), 115-123.

He, J., Ren, Y., Zhu, C., \& Jiang, D. (2013). Variations in cadmium, mercury and copper accumulation among different rice cultivars in the Yangtse River Delta, China. Journal of Chemical and Pharmaceutical Research, 5(12), 49-53.

Huo, Y., Du, H., Xue, B., Niu, M., \& Zhao, S. (2016). Cadmium Removal from Rice by Separating and Washing Protein Isolate. Journal of Food Science, 81(6), T1576-T1584. http://dx.doi.org/10.1111/1750-3841.13323.

Hussain, I., Khan, M. A., \& Ali, K. (2011). Comparative studies of heavy metals in wheat growing in different environmental conditions. Journal of the Chemical Society of Pakistan, 33(4), 499-502.

Jaishankar, M., Tseten, T., Anbalagan, N., Mathew, B. B., \& Beeregowda, K. N. (2014). Toxicity, mechanism and health effects of some heavy metals. Interdisciplinary Toxicology, 7(2), 60-72. http://dx.doi. org/10.2478/intox-2014-0009. PMid:26109881.

Jamali, M. K., Kazi, T. G., Arain, M. B., Afridi, H. I., Jalbani, N., Kandhro, G. A., Shah, A. Q., \& Baig, J. A. (2009). Heavy metal accumulation in different varieties of wheat (Triticumaestivum L.) grown in soil amended with domestic sewage sludge. Journal of Hazardous Materials, 164(2-3), 13861391. http://dx.doi.org/10.1016/j.jhazmat.2008.09.056. PMid:18977590.

JCR-VIS Credit Rating Company Limited. (2017). Rice sector update. Karachi, Pakistan: JCR-VIS. Retrieved from https://s3-us-west-2. amazonaws.com/backupsqlvis/docs/Rice201703.pdf 
Khan, K., Lu, Y., Khan, H., Ishtiaq, M., Khan, S., Waqas, M., Wei, L., \& Wang, T. (2013). Heavy metals in agricultural soils and crops and their health risks in Swat District, northern Pakistan. Food and Chemical Toxicology, 58, 449-458. http://dx.doi.org/10.1016/j. fct.2013.05.014. PMid:23721688.

Khan, M. U., Malik, R. N., Muhammad, S., Ullah, F., \& Qadir, A. (2014). Health risk assessment of consumption of heavy metals in market food crops from Sialkot and Gujranwala Districts, Pakistan. Human and Ecological Risk Assessment, 21(2), 327-337. http://dx.doi.org/1 0.1080/10807039.2014.913445.

Khan, S., Ismail, A., Gong, Y. Y., Akhtar, S., \& Hussain, M. (2018). Concentration of Aflatoxin M1 and selected heavy metals in mother milk samples from Pakistan. Food Control, 91, 344-348. http://dx.doi. org/10.1016/j.foodcont.2018.04.015.

Liang, H., Wu, W. L., Zhang, Y. H., Zhou, S. J., Long, C. Y., Wen, J., Wang, B. Y., Liu, Z. T., Zhang, C. Z., Huang, P. P., Liu, N., Deng, X.-L., \& Zou, F. (2018). Levels, temporal trend and health risk assessment of five heavy metals in fresh vegetables marketed in Guangdong Province of China during 2014-2017. Food Control, 92, 107-120. http://dx.doi.org/10.1016/j.foodcont.2018.04.051.

Mahmood, A., \& Malik, R. N. (2014). Human health risk assessment of heavy metals via consumption of contaminated vegetables collected from different irrigation sources in Lahore, Pakistan. Arabian Journal of Chemistry, 7(1), 91-99. http://dx.doi.org/10.1016/j. arabjc.2013.07.002.

Malik, R. N., Hussain, S. Z., \& Nazir, I. (2010). Heavy metal contamination and accumulation on soil and wild plant species from industrial area of Islamabad, Pakistan. Pakistan Journal of Botany, 42(1), 291-301.

Oosthuizen, J. (2012). Environmental health: Emerging issues and practice. Rijeka, Croatia: InTech. http://dx.doi.org/10.5772/1519.

Pendias, A. K., \& Pendias, H. (2001). Trace elements in soil and plants (3rd ed.). Boca Raton: CRC Press.

Rehman, Z. U., Sardar, K. H., Shah, M. T., Brusseau, M. L., Khan, S. A., \& Mainhagu, J. (2017). Transfer of heavy metals from soils to vegetables and associated human health risk in selected sites in Pakistan. Pedosphere, 28(4), 666-679. http://dx.doi.org/10.1016/ S1002-0160(17)60440-5.

Riazuddin, Khan, M. F., Iqbal, S., \& Abbas, M. (2011). Determination of multi-residue insecticides of organ chlorine, organophosphorus, and pyrethroids in wheat. Bulletin of Environmental Contamination and Toxicology, 87(3), 303-306. http://dx.doi.org/10.1007/s00128011-0325-9. PMid:21656043.

Roberts, J. R., \& Relgart, J. R. (2013). Recognition and management of pesticide poisoning (6th ed.). Washington: US EPA. Retrieved from http://npic.orst.edu/RMPP/rmpp_main2a.pdf

Roleda, M. Y., Marfaing, H., Desnica, N., Jónsdóttir, R., Skjermo, J., Rebours, C., \& Nitschke, U. (2019). Variations in polyphenol and heavy metal contents of wild-harvested and cultivated seaweed bulk biomass: Health risk assessment and implication for food applications. Food Control, 95, 121-134. http://dx.doi.org/10.1016/j. foodcont.2018.07.031.

Roya, A. Q., \& Ali, M. S. (2017). Heavy metals in rice samples on the Torbat-Heidarieh market, Iran. Food Additives and Contaminants Part B, 10(1), 59-63. http://dx.doi.org/10.1080/19393210.2016.12 47918. PMid:27782775.

United States Environmental Protection Agency - US EPA. (2007a). Method 3015A: Microwave assisted acid digestion of aqueous samples and extracts, Revision 1. Washington: US EPA.

United States Environmental Protection Agency - US EPA. (2007b). Method 7000B (SW-846): Flame Atomic Absorption Spectrophotometry, Revision 2. Washington: US EPA.

United States Environmental Protection Agency - US EPA. (2010). Risk-based concentration table. Washington: US EPA.

Vanita, C., Piar, C., Avinash, N., Kaur, K. J., \& Pakade, Y. B. (2014). Evaluation of heavy metals contamination and its genotoxicity in agricultural soil of Amritsar, Punjab, India. International Journal of Research in Chemistry and Environment, 4(4), 20-28.

Wang, X., Zhang, Y., Geng, Z., Liu, Y., Guo, L., \& Xiao, G. (2019). Spatial analysis of heavy metals in meat products in China during 2015-2017. Food Control, 104, 174-180. http://dx.doi.org/10.1016/j. foodcont.2019.04.033.

World Health Organization - WHO. (2004). Joint FAO/WHO expert standards program codex alimentation commission. Geneva, Switzerland: World Health Organization.

Zhuang, P., McBride, M. B., Xia, H., Li, N., \& Li, Z. (2009). Health risk from heavy metals via consumption of food crops in the vicinity of Dabaoshan mine, South China. The Science of the Total Environment, 407(5), 15511561. http://dx.doi.org/10.1016/j.scitotenv.2008.10.061. PMid:19068266. 